\title{
JURIDICAL ANALYSIS OF THE EMPLOYMENT RELATIONSHIP REGULATION CONCERNING PARENTING \\ BY BABYSITTER
}

\author{
Gwendolyn Ingrid Utama; Satrya Pangadaran Marpaung \\ Faculty of Law, Pelita Harapan University, Jakarta, Indonesia \\ Email: gwen.ingrid@gmail.com; spm1084@gmail.com
}

\begin{abstract}
The need for childcare service is a phenomenon in households where parents can not function to nurture children on a full-time basis. Children, especially at the age of golden age, is an "asset" for the nation future because at that age the child absorbs and explores all the basic capabilities of the surrounding environment. Childcare services not only show people who are more mature to the child, but are also expected to be companions who can set a good example and provide a sense of security in meeting the basic needs of children. Childcare services performed by babysitters are ultimately established on the basis of employment relationships with the employer (in general the parents of the child). The employment relationship has not been regulated in detailed legislation yet, there are only general guidelines and arrangements through the relevant Minister. For this purpose, the research focuses the problem on the legal policy regarding the employment relationship between the babysitter and the employer, and analyzes the ideal arrangements for each party in the employment relationship (including employment agencies) in order to create justice for each party. The purpose of this study is to be able to trace each legal policy and generate suggestions for the ideal arrangement in the employment relationship that can create justice for every party involved.
\end{abstract}

Keywords: childcare service, employment relationship, babysitter

\section{A. INTRODUCTION}

Humans as social beings need interaction with each other to build relationships between them. Relationships between humans can be established in various forms such as friendships, colleagues in work, family, and others. One form to build a family is through marriage which is interpreted under Article 1 of Law Number 1 of 1974 on Marriage (Marriage Law) as an inner bond between a man and a woman as husband and wife with the aim of building a happy and eternal family based on belief in the one and only God. This inner bond continues to create a life together in a household.

According to the Great Dictionary of Indonesian, household defines as "in relation to the home affairs; about family" (https://kbbi.kemdikbud.go.id/entri/rumah tangga, accessed on August 23, 2017). The definition of affair is "something that is related

Yustisia Vol. 7 Number 3 (Sept.-Dec. 2018)

Juridical Analysis Of The Employment ...

C2018; This is an Open Acces Research distributed under the term of the Creative Commons Attribution Licencee (https://Creativecommons.org/licences/by/4.0), which permits unrestricted use, distribution, and reproduction in any medium, provided the original works is properly cited. 
or has something to do with" (https://kbbi.kemdikbud.go.id/entri/urusan, accessed on August 23, 2017). Based on the notion of household and affair, household affair can be described as something related to life in the home and the family.

In general, the family consists of mother, father and the children; the entire house (https://kbbi.kemdikbud.go.id/entri/keluarga, accessed on August 23, 2017). Children are part of the family thus they are also part of household. Therefore, the matters relating to the management of children are also the responsibility of home affairs.

Based on the 2016 Indonesian Health Profile published by the Indonesian Ministry of Health concerning "2016 Indonesian Health Profile Data and Information" in tables 1.5 and table 1.8 (Indonesian Ministry of Health, 2017) the age of children is divided into several categories, namely:

1. Newborn : 0 years old

2. Infant : 0 - 2 Years

3. Toddler : 0-4 Years

4. Preschool : 5-6 years

Idad Suhada concluded that early childhood is a child aged 0-8 years who is in the stage of growth and development, both physically and mentally (Idad Suhada, 2016: 110-117). Even though Idad Suhada concluded early age at 0-8 years old, he divided the category further into children in the first year (6 to 12 months); children in the second year (1 to 2.6 years); late childhood (age 3 to 4 years); early childhood (4 to 6 years); and late childhood (6 years until individuals become sexually mature, 13 years for girls and 14 years for boys).

Human life has 2 (two) psychological processes, namely growth and development. Both of these processes take place interdependently, means that they depend on each other; can not be separated but can be distinguished to emphasize its usage (Idad Suhada, 2016: 23). Growth is related to physical changes quantitatively which involve size increasing and biological structure, while development is a process that takes place from a global situation and is less differentiated until the differentiation, articulation, and integration gradually increase with the entirely of the child; the part of value absorption will gradually become more evident and clearer in the whole framework (Idad Suhada, 2016: 24-25).

Research on brain development shows that the brain develops faster in the first three years of life (ILO, 2015: 1). The development that occurred in the first four years is as large as the development that occurred during the next fourteen years, and after that period the child's brain development will stagnate. That is why this period is called the golden age, because after passing this period, any intelligence capability achieved by each individual will no longer increase (Loeziana Uce, 2017: 79). At the age which often called the golden age, almost all potential children experience

570 Yustisia Vol. 7 Number 3 (Sept.-Dec. 2018) Juridical Analysis Of The Employment ... 
sensitive times to grow and develop quickly and superbly (Idad Suhada, 2016: 110). If children are stimulated intensively, they will be able to carry out their development tasks well. The treatment and care received at the golden age determines the future condition of children to live personally both as individual and part of the society.

The role of parents who have the responsibility to prepare their children's future through good growth and development, cannot always be fulfilled twenty-four hours each day due to several reason, including not being able to; do not know; and do not want to. The inability of parents to fulfill their roles can be caused by various reasons such as lack of time with children because of work and physical or mental conditions which makes parent not possible to taking care the childern. The nescience is also one of the reason parents not fulfilling their role to children, for example the child is the first child and under the reason that parents do not have the experience of taking care child and afraid to make mistakes because they lack the knowledge etc. Sometimes there are parents who do not want to bother themselves taking care of children without assistance, or even do not want to take care of their children. These three reasons resulted in a high demand for childcare services. Child care services can be divided into 2 (two) types, namely through daycare or employing other people.

One form of childcare services is employing other people to take care of the children which barely becomes an alternative for parents who need parenting assistance. The general term is called babysitter. The job of babysitter is a babysit which according to some dictionaries is interpreted as follows:

1. look after a child or children are out (take care of a child or children while parents are out) (https://en.oxforddictionaries.com/definition/babysit, accessed on April 28, 2017).

2. to take care of someone's baby or child while that person is out, usually by going to the person's home (take care of the baby or child while parents are out, usually at their house) (http://dictionary.cambridge.org/dictionary/ english/ babysit, accessed on 28 April 2017).

3. to care for children usually during a short absence of the parents (take care of children usually during the absence of parents in a short time) (https://www. merriam-webster.com/dictionary/babysit, accessed on 28 April 2017).

Based on this description, the definition of babysit in general is the job of looking after or caring for a baby or child as long as the parents of the child cannot carry out. The person who do such job called a babysitter. This term is later known in Indonesia as a child caregiver in the household affairs.

The Indonesian Minister of Manpower And Transmigration Decree Number 197 Of 2014 On Determination of Indonesian National Work Competency Standards for Individual Services that Serve Households; Activities that Produce Goods and 
Services by Self-Used Households to Meet the Needs of the Individual Group of Services that Serve Babysitters (Babysitter) provides a definition of baby sitter as a person who helps parents to care for, care for, nurture and educate children when parents are not in the house (Decree of the Minister of Manpower and Transmigration of the Republic of Indonesia Number 197 of 2014 on Determination of Indonesian National Work Competency Standards in the Category of Individual Services Serving Households; Activities that Produce Goods and Services by Households Used Alone to Meet Needs The Basic Group of Individual Services Serving Baby Sitter Households: 4). The decision shows that the work of caring for children is categorized as an individual service that serves households, with the basic category of individual services in the household, the name of the job/profession referred to as the baby sitter, and the area of work is looking out; parenting; and baby care. Thus child caregivers can also be categorized as domestic workers.

Childcare has become one of various domestic work. Although in this kind of job, it is clear that there is a employment relationship between the worker and the employer, but it has not been regulated under Law Number 13 of 2003 on Manpower (Labor Law) because the law only reaches employment relationship in the formal sector, while babysitting is classified as informal.

The informal term based on the ILO is stated as "informal economy" proposed by the "informal sector" to accommodate "all economic activities that are, in law or practice, not covered or insufficiently covered by formal arrangements" (International Labor Office, 2015: 4), which means that work in the informal sector or as the informal economy is an activity that is either in law or practice is not protected by formal regulation. Thus the regulation regarding this type of work cannot be based on the Labor Law. The Indonesian government is increasing the awareness due to the problems faced by families in ensuring their child's care while they work, and given the fact that the lack of childcare leads to inefficient functioning of the labor market, underutilized public investment in human resources and inadequate care for next generation (ILO, 2016: 3-4).

Other informal definition are: (a) easy to enter in terms of expertise, capital, and organization; (b) family-owned companies; (c) operate on a small scale; (d) labor intensive production and using simple technology; and (e) unregulated and competitive markets (IBRA, 2009: 12). The work with this description was accommodated in the Republic of Indonesia Minister of Manpower Regulation Number 2 of 2015 on the Protection of Domestic Workers (hereinafter abbreviated as Permenper PPRT).

Based on the definition stated in Article 1 number 2 of the PPRT Permenaker, household work is work carried out within the scope and interests of the household. Other definitions relating to subjects that can be involved in the work, included in the ministerial regulations include:

572 Yustisia Vol. 7 Number 3 (Sept.-Dec. 2018) Juridical Analysis Of The Employment ... 
1. Domestic Workers, hereinafter abbreviated as PRT, are people who work for individuals in the household to carry out household work by receiving wages and/or other forms of rewards (Article 1 number 1 of the PPRT Permenaker).

2. Domestic Workers Employers are individuals who employ domestic workers by paying wages and/or other forms of rewards (Article 1 point 3 of the Minister of Manpower Regulation).

3. The Domestic Worker Supplier Institution, hereinafter abbreviated as LPPRT, is a enterprise received written permission from the Governor or appointed official to recruit and distribute domestic workers (Article 1 point 4 of the Permenaker PRRT).

The three definitions provided in the PPRT Permenaker can be said to be in accordance with the type and actors of childcare by the babysitter. However, the regulation only provides general provisions (not specifically in the field of childcare) in household work and without sanctions on employment relationship, therefore the effectivity of these regulations is not measurable.

The description above shows that regulation of special employment relationships in the field of childcare is important considering the potential for children's growth and development to build the nation's future cannot be separated from the pattern of caring the childhood, especially the golden age. For this reason, it is necessary to conduct research with the topic of regulating the childcare relationship by the babysitter to achieve an adequate future for the nation.

\section{B. PROBLEM STATEMENT}

The description on the background shows that the research is necessary under the following formulation of the problem:

1. How is the employment relationship between babysitters and employers in Indonesia regulated?

2. What is the ideal arrangement of regulation for the use of babysitters for workers, employers so that fairness in work relations for both parties can be realized?

\section{RESEARCH METHODS}

Legal research is a scientific activity based on methods, systematics, and certain thoughts that aim to study one or several symptoms of a particular law by analyzing, as well as conducting an in-depth analysis of the legal facts to seek a solution of the problems arise in the symptoms concerned (Soerjono Soekanto, 1986: 43). Research is a tool used by humans to strengthen, foster and develop knowledge (Soerjono Soekanto, 2006: 5). 
Legal research is a process of finding legal regulation, legal principles, and legal doctrines in order to answer the legal issues arise, this is different from descriptive science research which examines the truth of whether it is caused by particular factor, legal research is conducted to produce new arguments, theories or concepts as prescriptions in solving problems faced (Peter Mahmud Marzuki, 2011: 35). If the descriptive nature of the expected answer is true or false, the expected answer in legal research is right, appropriate, inappropriate or wrong. Thus it can be said that the results obtained in legal research already contain the value (Peter Mahmud Marzuki, 2011: 35).

The research method used in this study is the normative legal research method. Normative legal research method is a legal research method which the object is legal norms or legal substance, with the aim of examining the quality of legal norms based on essential elements and the main objectives of the law are justice, expediency and legal certainty. Based on the definition of the normative legal research method, this study uses regulation of labor law as the object of research in obtaining solution of the legal issues described in the previous section.

The data used in this study are secondary data consisting of the following legal materials:

1. Primary Legal Materials, with binding powers such as basic norms, legislation or court decisions. Primary Legal Materials in this study include:

a. Civil Code

b. Law Number 13 of 2003 on Manpower

c. Indonesian Ministerial of Manpower and Transmigration Regulation Number 2 of 2015 on Protection of Domestic Workers

d. Decree of the Indonesian Minister of Manpower and Transmigration Number 197 of 2014 on Determination of Indonesian National Work Competency Standards for Category of Individual Services Serving Households; Activities that Produce Goods and Services by Self-Used Households to Meet the Needs of the Individual Group of Services that Serve Babysitters (Baby Sitters)

e. ILO Convention Number 189 on Decent Work for Domestic Workers

2. Secondary Legal Materials, as the materials that provide an explanation of primary legal materials and their unbinding content, such as books, papers, scientific journals, research results, and other scientific works relating to labor law both formal and informal sectors.

3. Tertiary Legal Materials, as materials that provide instructions and explanations for primary legal materials and secondary legal materials, such as general dictionaries, legal dictionaries, encyclopedias, and labor-related websites. 
The method of research used will determine the analysis in the study. The nature of the analysis to be used in this study is qualitative method. The qualitative analysis referred to in this study is an analysis which formulation of justification is based on the quality of the opinions of legal experts, doctrines, theories, and the formulation of the norm itself.

In legal research there are several approaches that can be used by researchers to obtain information of the issues being examined and find the answers. According to Peter Mahmud Marzuki, the approaches used in legal research consist of 5 (five) approaches, namely (Peter Mahmud Marzuki, 2011: 93):

1. Statue Approach

The statute approach is carried out by examining all laws and regulations relating to the legal issues being addressed. The statute approach will provide an opportunity for researchers to study the consistency and suitability of a regulation one another and the Constitution, or between regulations and laws. Researchers need to look for legislation ratios (can be interpreted as the reason and purpose of creating law) and ontological basis (can be interpreted as the reason for the existence of a law. This can be obtained from the ministry or agency that submits the Draft Law (RUU). In the submission of the draft, there will be a demand for the establishment of the law) from the certain regulation submitted.

2. Case Approach

The case approach is carried out by reviewing cases related to the issues faced which have become court decisions with permanent legal force. The main focus in the case approach is reasoning or ratio decidendi, as the consideration of the court to reach at the decision.

3. Historical Approach

The historical approach is carried out by examining the background of the issue and the development of regulations. Historical approach is required if the researcher considers that philosophical disclosure and paradigm when an issue examines born does have relevance to the present.

4. Comparative approach

This approach is conducted by comparing the laws of a country with laws from one or more other countries on the same issue. Besides the law, court decisions in several countries for the same case could be the the source if information for the researcher. The function of this approach is to obtain the similarities and differences between the laws. 
5. Conceptual Approach

The conceptual approach conducts from the perspective and doctrines that develop in law. By studying the views and doctrines in law, researchers will find ideas to build legal definition which relevant to the issues. The understanding of these views and doctrines provide assistance for researchers in building a legal argument to solve the issues arise.

Based on the types of approaches by Peter Mahmud Marzuki, this study uses a statute approach.

\section{DISCUSSION AND RESEARCH RESULTS}

\section{The Regulation of Babysitter Employment Relationships with Employer in Indonesia}

The quality of the babysitter's regulation illustrates the importance of babysitters' existence in Indonesia. Generally and specifically, the regulations that support the employment relationship between babysitters and employers are as follows:

a. The Civil Code ;

b. Indonesian Ministry of Manpower and Transmigration Regulation Number 2 of 2015 on Protection of Domestic Workers (Permenaker PRRT); and

c. Decree of the Indonesian Minister of Manpower and Transmigration Number 197 of 2014 on Determination of Indonesian National Work Competency Standards for Category of Individual Services Serving Households; Activities that Produce Goods and Services by Self-Used Households to Meet the Needs of the Individual Group of Services that Serve Babysitters (Baby Sitters) (hereinafter referred to The Decision of The Minister of Labor Number 147 of 2014).

The regulation that govern in general is the Civil Code because basically the employment relationship between the babysitter and the employer is civil relations, therefore the provisions of the Civil Code still need to be considered in the employment relationship. Specifically, the certain regulation regarding the employment relationship between the babysitter and the employer is the Kepmenaker 197/2014.

The specific regulation for babysitters are divided into regulation for employment relationships between babysitters and employers (regulated under Permenaker PPRT) and guidelines for implementing work as babysitters (regulated under The Decision of The Minister of Labor Number 147 of 2014).

In regards of the employment relationship between the babysitter and the employer, it has only reached the Ministerial regulation level which regulates 
general provision (not specifically mention the babysitter, however domestic workers can be categorized as a domestic worker).

The applicable labor law has not yet regulated certain employment relationship due to the reason that scope of the law is the formal sector, while this relationship is a employment relationship in the informal sector. ILO Convention Number 189 has actually provided a basic provision regarding the employment relationship of domestic work which also includes child care, nevertheless the government of the Republic Indonesia has not ratified the convention until this research conducted.

\section{a. PPRT Permenaker}

This regulation was made with the intention of providing protection to domestic workers due to the cases of violence against domestic workers. This regulation describes the requirements to become domestic workers and employers, as well as their respective rights and obligations. The employment relationship between is also regulated in the regulation. In addition to workers and employers, the Permenper PPRT also regulates the supplier of Domestic Workers, such as the requirements; right; and supplier obligations and their relationship with workers and employers.

Provisions for workers and employers have no sanctions, therefore the provisions can be categorized as recommendations or guidelines. Article 27 paragraph (1) of the Permenper PPRT states that "Governors or appointed officials can impose administrative sanctions for violations of the provisions stipulated in this Ministerial Regulation". These provisions can only be implemented against suppliers due to certain administrative sanctions form is in the written warnings; temporary suspension of part or all of LPPRT's business activities; and revocation of licenses.

\section{b. The Decision of The Minister of Labor Number 197 of 2014}

This Ministerial Decree is a regulation that provides guidance on the implementation of child's care babysitters.

The background section of The Decision of The Minister of Labor Number 147 of 2014 states that the design of the substance of this decision is an initiative of the national employment group coordinated by the Directorate of Course and Training of the PAUDNI Directorate General Ministry of Education and Culture and the Directorate of Standardization and Competence of the Ministry of Manpower and Transmigration in collaboration with the Profession Association, The Association of Indonesian Family Planning Training Organizers (HIPPTAKI) and the Indonesian Workers Training Association (AP2TKI) carried out development activities from SKKNI TLRT to RSKKNI groups of baby sitters. The same section also states that the 
intention of the initiator to compile this matter is to reduce infant mortality and improve infant health among rural and urban communities that requires job of Baby Care adjusted to the demands as ILO provisions for decent work for workers who serve households (Domestic Worker of Report of ILO Geneva, 100.IV.2A.2011), as for the community can develop knowledge, skills and minimum work attitudes that must be owned by someone to get a certain position in the field of caregivers (Babysitter) that apply nationally and internationally (Rear Lata section The Decision of The Minister of Labor Number 147 of 2014).

The Background Section of this regulation also states that individual services serving households, especially the baby sitter group, indicate a shift in management services from traditional to innovative that require work ability that includes aspects of knowledge, skills and attitudes relevant to job implementation and job requirement in accrodance with the development of science and technology. This means that the state has acknowledged that child care work is a job that has a big role in the household, as seen in the statement "there is a shift in governance services from traditional to innovative ones that require work ability which includes aspects of knowledge, skills and attitudes" .

The Decision of The Minister of Labor Number 147 of 2014 even provides definitions of the terminology "baby", "babysitter", "babysitting", "caring for babies", and "babysitting". This shows that the government has seriously directed its attention to the work competence of the babysitter through these regulations. The purpose of this decision is to be used as a reference for establishing certification bodies managed by association communities, professional training associations, experts training of Baby Sitters, so that the demands of national examiners (examinators) and/or competency assessors are expected also referring to the competency scheme, it is expected that there will be no misguided program design between community education and the design of the certification program (must work together).

The Indonesian National Work Competency Standards (SKKNI) of the Baby Sitter Group described in the Kepmenaker is used as a reference for (The Decision of The Minister of Labor Number 147 of 2014):

1) For education and training institutions

a) Provide information for program and curriculum development

b) As a reference in organizing training, assessment and certification 
2) For the enterprise and the labor purpose

a) Helps in recruitment

b) Helps assess performance

c) Assist in compiling job descriptions

d) Develop specific training programs based on the needs of the busi-ness/industry

3) For test and certify institutions

a) As a reference in formulating certification program packages according to their qualifications and levels.

b) As a reference in organizing training, assessment and certification

The contents of The Decision of The Minister of Labor Number 147 of 2014 are in the form of guidelines for preparing babysitters with certain competencies in order to increase the babysitter's quality of work.

\section{Ideal Regulation on the Use of Babysitter Services for Workers and Equitable Employers on Employment Relations for Both Parties}

Babysitter services have now become a necessity for households whose family members consist of adults and children (can have more than one child). The general condition that requires the services of a babysitter is the condition where both parents work, where they cannot taking care the child. In its development these days, the availability of babysitter services is not only used by family with such household conditions but many parents use the services of a babysitter even though both parents do not really have much work or they simply have a lot of time together with their children. Babysitter services are no longer only used by those who are not able (either time, energy, or skills) to care for their children, even those who have the ability but still choose to use the services of a babysitter.

Law Number 13 of 2003 on Manpower Article 1 number 15 defines work relations as the relationship between employers and workers/laborers based on work agreements, which have elements of employment, wages, and orders; and Article 1 number 14 defines a work agreement as an agreement between a worker/laborer and an employer that contains the terms of the work conditions, rights and obligations of the parties. These definitions, even though are aimed at formal sector work, can also be implemented towards the relationship between the babysitter and the employer.

Based on the foregoing description, it concludes that the legal basis of the employment relationship between the babysitter and the employer is the Civil Code (in the subject matter of law and engagement) and the PPRT Permenaker. The two regulations have not guaranteed the relations between worker and the 
employer to be carried out properly because civil relations only depend on the engagement. If the relationship is based on a commitment, then it is based on the agreement. Because the employment relationship between the babysitter and the employer is included in the informal sector employment relationship, generally it is not in the form of written agreements and the contents of the agreement are not detailed prior to the agreement is reached. Problems that arise in the future will be resolved by means of "anything" such as by bargaining request that often make one party feel disadvantaged or disagree but are forced to agree. The guidelines provided through The Decision of The Minister of Labor Number 147 of 2014 can actually be used as a basis for workers to improve their quality so that work relations can be of higher quality compared to those guidelines. unfortunately, The Decision of The Minister of Labor Number 147 of 2014 is not an obligation to establish employment relationships in the area of infant care.

Both parties in the baby care work agreement are certainly potentially harmed. Without a coercive arrangement, the potential loss is more wide open. Examples of losses regarding wages (which have no regulations) from both parties are as follows:

a. The babysitter as the party that receives the job, may be harmed in terms of payment of wages that do not match the load of work carried out. Work that requires him to always be with the baby he nurtures continuously so that rest periods become less reasonable, making his work classified as "heavy". The heavier the work, naturally the greater the wages that should be obtained.

b. Employers can also be disadvantaged in terms of payment of wages that are not in accordance with the quality of work carried out by the babysitter, for example the babysitter does not have the knowledge and skills as a babysitter that is expected to help employers to care for the baby. As an illustration, employers have agreed to employ a babysitter based on a description of the experience conveyed by the babysitter. Then the employer agrees to the wages requested by the babysitter because the babysitter looks experienced and promises to take good care of the baby's employers. When starting work, it turns out that the employer thinks the babysitter is less able to do the work of caring for the baby so that the wages he agrees are not in accordance with the implementation of the babysitter work that he expected.

This wage loss is only one of the potential other losses that can be experienced by the parties, the regulation are highly demanded to bring justice for both parties.

ILO Convention No. 189 of 2011 on Decent Work for Domestic Workers that has not been ratified by the State of Indonesia, contains provisions that can be used as guidelines for the implementation of work agreements for the household work. The job of babysitting is work that is included in the household, therefore 
if it is ratified, the provision of the convention can be implemented in the employment relationship between the babysitter and the employer.

The justice demanded in this employment relationship is justice which provides a balance between the rights and obligations of both parties. As an example in regards of the wages, it would be fair if the amount of the wage is compatible with the workload and work quality of the babysitter. Thus, it wll decrease the feel of disadvantaged because the employment relationship have reached balance between giving and receiving. Therefore, the justice as a form of fairness is in accordance with the justice intended by John Rawls.

Issues that need to be regulated for workers and employers of babysitter work care must contain the rights and obligations of the parties. These rights and obligations will limit the act of the parties in an arbitrary. Based on research on existing regulations, the results of this study found that there are several topics that need to be added to the Permenper PPRT in order that the employment relationship have a certain quality, including:

1) the rights and obligations of the parties that are freely determined by the parties, must be agreed prior to the the entry into force of the agreement;

2) there are sanctions if the period of the agreement is not fulfilled, hereinafter is the compensation;

3) the employment time, including time to rest and time to standby;

4) minimum wages in accordance with the competencies of workers as stipulated in The Decision of The Minister of Labor Number 147 of 2014; and

5) if possible, it can be required that each babysitter must have certificate with a 5-year validity period issued by the certification institution designated by a government.

If all of these are manifested in the PPRT Permenaker, it can have an impact on the minimum wage because in order to get certification requires additional time and costs.

\section{E. CLOSING}

\section{Conclusion}

According to the discussion above, it can be concluded that:

a. The regulation of the employment relationship between the babysitter and the employer are contained in the Civil Code as a rule of public civil relations; PPRT Permenaker which is a special rule for domestic work which includes babysitter babysitting work; and The Decision of The Minister of Labor Number 147 of 2014 are guidelines for babysitters to improve their quality in 
work. All regulations provided have not been able to maintain good employment relationship between the babysitter and its employers.

b. There are several topics that need to be added to the PPRT Permenaker to strengthen the quality of the employment relationship between the babysitter and the employer due to the balance condition which have not been reached. If all these issues are provided in the regulation, the employment relationship will be protected under ceritain provision, if in any case it is not in accordance with the provision, the employment relationship is not protected by the regulation.

\section{Suggestion}

The government needs to immediately ratify ILO Convention Number 189 due to the importance to be implemented on the employment relationship of the babysitter with employers that supports the realization of justice. Further, the products of the ratification can be proceed through the ministerial regulation which specifically regulates the baby care according to The Decision of The Minister of Labor Number 147 of 2014.

\section{BIBLIOGRAPHY}

\section{Books:}

Marzuki, Peter Mahmud, 2011, Penelitian Hukum (Legal Research), Kencana: Jakarta

ILO, 2015, Pengasuhan Anak Berbasis Masyarakat: Manual Pelatihan/International Labour Office (Community Based Child Care: Manual Training/ International Labour), ILO: Jakarta.

International Labor Office, 2015, International Labour Conference: Recommendation 204 Concerning the Transition From the Informal to the Formal Economy, Geneva: International Labor Organization

Kedeputian Evaluasi kinerja Pembangunan, 2009, Peran Sektor Informal sebagai Katup Pengaman Masalah Ketenagakerjaan (The Role of The Informal Sector as a Safety Value for Labour Problems), BPPN: Jakarta.

Kementerian Kesehatan Republik Indonesia, 2017, Data dan Informasi Profil Kesehatan Indonesia 2016 (Indonesian Health Profile Data and Information), Kementerian Kesehatan Republik Indonesia: Jakarta.

Suhada, Idad, 2016, Psikologi Perkembangan Anak Usia Dini (Psychology of Early Childhood Development), PT. Remaja Rosdakarya: Bandung. 
Soekanto, Soerjono, 1986, Pengantar Penelitian Hukum (Introduction to The Legal Research), UI Press: Jakarta.

Soekanto, Soerjono, 2006, Sosiologi Suatu Pengantar (Sociology as an Introduction), Jakarta: Raja Grafindo Persada

\section{Journals:}

Uce, Loeziana, 2015, "The Golden Age: Masa Efektif Merancang Kualitas Anak", Jurnal Bunayya, Banda Aceh: Fakultas Tarbiyah dan Keguruan Universitas Islam Negeri Ar-Raniry DarussalaM, Vol. 1 No. 2

\section{Regulations:}

Code of Civil Law

Law Number 1 of 1974 on Marriage (State Gazette of The Republic of Indonesia Number 1 of 1974)

Law Number 13 of 2003 on Manpower (State Gazette of The Republic of Indonesia Number 39 of 2003)

Indonesia Minister of Manpower Regulation Number 2 of 2015 on the Protection of Domestic Workers

Indonesian Minister of Manpower And Transmigration Decree Number 197 Of 2014 On Determination of Indonesian National Work Competency Standards for Individual Services that Serve Households; Activities that Produce Goods and Services by Self-Used Households to Meet the Needs of the Individual Group of Services that Serve Babysitters (Babysitter)

\section{Internet:}

https://kbbi.kemdikbud.go.id/entri/rumah\%20tangga

https://kbbi.kemdikbud.go.id/entri/urusan

https://kbbi.kemdikbud.go.id/entri/keluarga

https://en.oxforddictionaries.com/definition/babysit

http://dictionary.cambridge.org/dictionary/english/babysit

https://www.merriam-webster.com/dictionary/babysit 